\title{
A MÍDIA E O SENTIMENTO DE \\ INSEGURANÇA: estudo de recepção sobre o \\ Programa "Barra Pesada" \\ Benjamin André Honorat
}

Curso: Mestrado em Sociologia

Data de defesa da tese: 8 de julho de 2005

Orientadora: Prof ${ }^{\mathrm{a}} \mathrm{Dr}^{\mathrm{a}}$ Lourdes Maria Bandeira

\section{Resumo}

O presente trabalho insere-se no tema dos efeitos da mídia sobre a formação da opinião pública. Mais precisamente, trata-se de determinar o impacto da televisão sobre o sentimento de insegurança, definido como uma opinião política pedindo mais medidas de segurança no objetivo de proteger a sociedade contra a criminalidade.

A problemática deste trabalho é centrada em um programa de televisão, "Barra Pesada", que passa cotidianamente no Canal Brasília. Trata-se de fazer um estudo de recepção, a fim de compreender como os indivíduos decodificam as informações apresentadas por este tipo de programas policialescos. Do ponto de vista teórico, foram utilizados os trabalhos de Stuart Hall, que apresentam uma concepção do processo de comunicação centrada no receptor. Quanto às hipóteses, foram tiradas do pensamento de Pierre Bourdieu sobre a noção de capital cultural, e de William Gamson, que mostra o papel da vida cotidiana.

Através de um conjunto de grupos focais, vários elementos de conclusão destacam-se. Em primeiro lugar, as reações às informações audiovisuais são sempre complexas e múltiplas. Porém, pode-se mostrar que o processo de decodificação é ligado a fatores sociais. 
A vida cotidiana das pessoas entrevistadas (que muda em função do lugar de moradia, do poder aquisitivo) exerce uma influência sobre sua visão das informações divulgadas pela mídia.

Condições de vida humildes podem, por exemplo, moldar esquemas de decodificação alternativos no que diz respeito ao enquadramento escolhido pelos programas policialescos. Ao contrário, o fato de ter acesso a um certo nível de consumo cria as condições favoráveis para ser mais sensível ao sentimento de insegurança apresentado por estes programas. No entanto, mesmo desenvolvendo esquemas de decodificação alternativos, resistindo ao discurso presente na mídia, como sugere William Gamson, as pessoas desprovidas de capital cultural nem sempre se sentem capazes de defender um verdadeiro posicionamento crítico, o que parece confirmar os trabalhos de Pierre Bourdieu.

Palavras-chave: sentimento de insegurança, codificação, decodificação, capital cultural. 